\title{
Epidemiology of carbapenemase producing Enterobacteriaceae in a general hospital
}

\author{
Amina Kandeel ${ }^{1,2}$ \\ ${ }^{1}$ Department of Medical Microbiology and Immunology, Faculty of Medicine, Mansoura University, Egypt \\ ${ }^{2}$ Microbiology Department, King Khaled General Hospital, Hafer Albatin, Saudi Arabia
}

\begin{abstract}
Objective: Detect the presence of carbapenemases producing Enterobacteriaceae (CPE) and associated epidemiological, microbiological, and clinical characteristics of patients in our hospital

Methods: During 15 months period, all non duplicate Enterobacteriaceae isolates with reduced susceptibility to carbapenem detected by MicroScan WalkAway system and confirmed by E test were collected. These suspected isolates were further screened by modified Hodge test and carbapenemase inhibition discs to identify CPE.

Results: Out of 54 suspected Enterobacteriaceae isolates, 44 (88.5\%) isolates were either extended spectrum beta-lactamases (ESBLs) or AmpC producers with porin loss whereas 10 isolates (18.5\%) were confirmed to produce carbapenemase representing (0.74\%) of the total Enterobacteriaceae. Among these 10 isolates, 6 were OXA 48 producers and 2 isolates were class B and class A each. Six out of the 10 CPE were detected in ICU and specimen source was tracheal aspirate in 5 CPE isolates. All CPE isolates were sensitive to colistin and all but one to tigecycline. All patients had history of previous antibiotic exposure and hospital stays for more than 5 days.
\end{abstract}

Conclusion: Although CPE is not the main cause of carbapenem resistance in Enterobacteriaceae in our setting, its emergence there represents a serious infection control and therapeutic challenge. This mandates its early detection using MHT and carbapenemase inhibition tests together with strict infection control measures to limit its spread. $J$ Microbiol Infect Dis 2015;5(2): 57-62

Key words: Enterobacteriaceae, carbapenemases, resistant organisms, carbapenems, epidemiology

\section{Genel hastanede karbapenemaz üreten enterobacteriae epidemiyolojisi}

\section{ÖZET}

Amaç: Genel hastanede Karbapenemaz üreten Entereobakterlerin (KÜE) tespiti, epidemiyolojisi, mikrobiyolojisi ve hastaların klinik karakteristik özelliklerinin belirlenmesi.

Yöntemler: On beş aylık dönem içinde, dublike olmayan MikroScan WalkAway sistemi ile karbapenem duyarlılığı azalmış ve E test ile doğrulanan Enterobakterler tespit edildi. Daha sonra modifiye Hodge testi ve disk inhibisyon yöntemi ile karbapenemaz üreten enterobakterler belirlendi.

Bulgular: Tespit edilen 54 enterobakter izolatı içinde 44 (\%88.5)'i genişletilmiş spektrumlu beta-laktamaz (GSBL) veya porin kayıplı AmpC üretiyordu. Bunun yanında 10 izolat (\%18.5) karbapenemaz üretiyordu. Karbapenemaz üreten izolatlatlar tüm enterobakterler içinde \%0.74 oranında idi. Bu 10 izolatın 6'sı OXA-48 üretirken 2'si grup B ve grup A idi. Bu 10 izolatın 6'sı yoğun bakım ünitesinde yatan hastalarda tespit edildi. Bu 6 izolatın 5'i trakeal aspiratta üredi. Tüm KÜE kolistine duyarlı idi, sadece 1 izolat tigesikline dirençli idi. Tüm hastalar öncesinde antibiyotik tedavisi almıştı ve 5 günden uzun süredir hastanede yatmakta idi.

Sonuç: Bizim ünitemizde karbapenem direnci başlıca KÜE bağlı olmasa bile KÜE tespit edilmiş olması enfeksiyon kontrol önlemleri ve tedavi yaklaşımlarının tekrar gözden geçirilmesini gerekli kılmaktadır. Bu da erken dönemde modifiye hodge testi ve karbapenemaz inhibisyon testlerinin beraber kullanılması ile KÜE erken tesbiti ve sıkı enfeksiyon kontrol önlemlerinin uygulanması ile yayılımının önlenmesi sağlanabilir.

Anahtar kelimeler: Enterebokterler, karbapenemazlar, dirençli organizma, karbapenemler, epidemiyoloji

Correspondence: Amina Kandeel, Microbiology Department, King Khaled General Hospital, Hafer Albatin, Saudi Arabia

Email: amina_449@yahoo.com

Received: 28 December 2014, Accepted: 20 March 2015

Copyright (C) Journal of Microbiology and Infectious Diseases 2015, All rights reserved 


\section{INTRODUCTION}

Resistance to broad-spectrum antimicrobials, such as the extended-spectrum cephalosporins, is a well recognized problem among Enterobacteriaceae. Carbapenems have served as the last choice to treat sever infections caused by these organisms. ${ }^{1}$ Carbapenem resistance in Enterobacteriaceae maybe caused by extended spectrum beta-lactamases (ESBLs) or AmpC enzymes joint with drug decreased permeability, due to loss of porins. ${ }^{2}$ Also, its increased use resulted in the emergence of isolates producing carbapenemases which belong to Ambler classes A, class B and class D. Molecular classes $A$ and $D$ include $\beta$ lactamases with serine at their active site, whereas molecular class $\beta$-lactamases are all metalloenzymes with an active-site zinc. The most common enzyme of class A carbapenemases is KPC which effectively hydrolyze carbapenems and are partially inhibited by clavulanic acid. It was identified in 1996 in the eastern United States then spread to many European countries and in South America. ${ }^{3-6}$ Class B metallo- $\beta$-lactamases (MBLs) are mostly of the VIM, IMP and NDM-1. They have been described Worldwide especially in Greece, Taiwan and Japan. They hydrolyze all $\beta$-lactams except aztreonam. Their activity is inhibited by EDTA but not by clavulanic acid. Most MBL producers are hospital acquired and multidrug-resistant Klebsie/la pneumoniae. l, $4,7^{2}$ The first identified class $D$ enzymes of the OXA-48 was in Turkey in $2003 .{ }^{8}$ Their distribution now includes countries in Europe, in the southern and eastern part of the Mediterranean sea and Africa. Their activity is not inhibited by EDTA or clavulanic acid3. In the Arabian Peninsula the first documented outbreak of carbapenem-resistant K. pneumoniae in Saudi Arabia was reported in Riyadh in 2010 and involved 20 patients. NDM1-producing isolates was reported in 2011 followed by detection of NDM-1, OXA-48 producers in Oman which suggests that carbapenemase producers are now emerging in the region..$^{9,10,11}$ risk factors for carbapenemases producing Enterobacteriaceae (CPE) infection include advanced age, severity of the underlying illness, intensive care unit (ICU) stay, earlier antibiotic exposure, invasive devices, organ or stem-cell transplantation, mechanical ventilation, and prolonged hospital stays. Clinical infections are usually healthcare associated mostly bacteremia, ventilator-associated pneumonia, urinary tract, and surgical site infections and have been associated with treatment failures and increased mortality. ${ }^{12,13}$ The rapidly increasing prevalence of Enterobacteriaceae harboring carbapenemases is alarming and its early detection has become mandatory as clinical failure associated with these enzymes has been described. Current guidelines recommend screen suspicious isolates with MICs of $\geq 0.5 \mathrm{mg} / \mathrm{l}$ for ertapenem and $\geq 1 \mathrm{mg} / \mathrm{l}$ for imipenem and meropenem for evidence of carbapenemase activity. ${ }^{14,15}$ The clinical laboratory standard institute (CLSI) has issued recommendations for phenotypic screening of carbapenemase producers among species of Enterobacteriaceae and included the modified Hodge test (MHT) as a confirmatory assay. ${ }^{16}$ But MHT often gives false-positive results with ESBL isolates or AmpC-hyperproducers of Enterobacteriaceae family. ${ }^{17}$ Carbapenemase inhibition tests with boronic acid derivatives (BA) and dipicolinic acid (DPA), joint with a temocillin disc offer a reliable phenotypic confirmation method for class A, B and OXA-48 carbapenemases respectively in Enterobacteriaceae..$^{18}$ To the best of the author's knowledge, carbapenemase producing Enterobacteriaceae (CPE) has not been studied before in eastern province. Hence, this study is planned to figure the frequency of CPE in our hospital and associated epidemiological, microbiological, and clinical characteristics of patients.

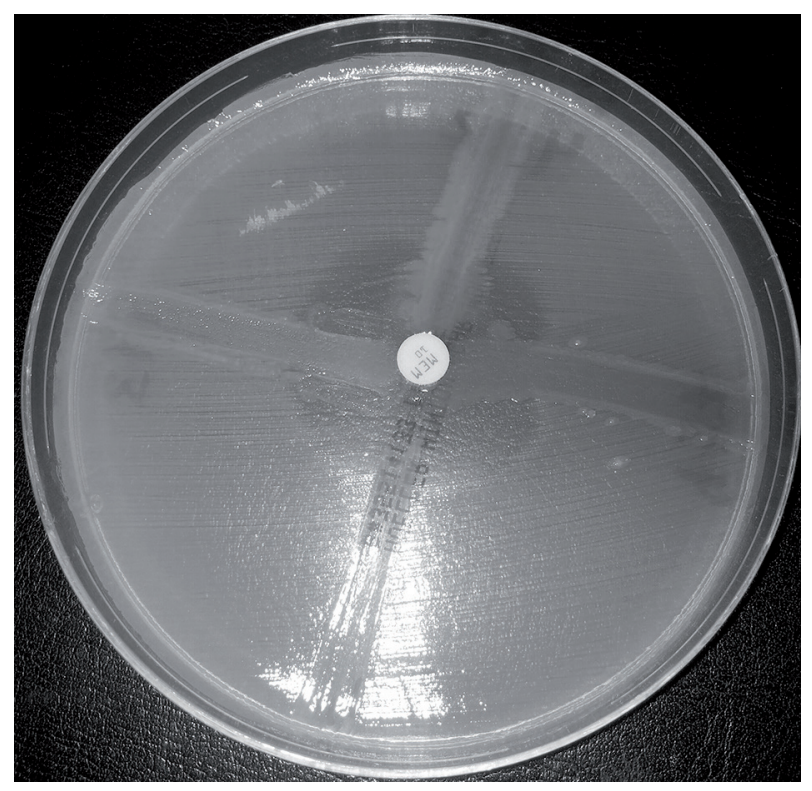

Figure 1. Modified Hodge test showing 1 positive isolate

\section{METHODS}

\section{Setting}

The study was carried out in King Khaled General Hospital (KKGH), eastern province, Saudi Arabia. During the study period (October 2012-December 2013) all non duplicate Enterobacteriaceae 
isolates that showed reduced susceptibility to carbapenem and resistant to third generation cephalosporins were subjected for further analysis. The demographic and clinical data of the patients with suspected isolates were recorded from their files. The article did not need an approval from the Ethics Committee.

\section{Microbiological methods}

The identification of Enterobacteriaceae and initial antimicrobial susceptibility testing (AST) were done using the MicroScan WalkAway system (Siemens, Sacramento, USA) using negative breakpoint combo42 (NBC42) panels. Results of AST were interpreted by Microscan software program, following Clinical and laboratory Standards Institute (CLSI) guidelines 16 The MICs of colistin and tigecycline were interpreted following the European Committee on Antimicrobial Susceptibility Testing (EUCAST) criteria for colistin ( $\leq 2$ and $\geq 4 \mathrm{mg} /$ liter for susceptible and resistant, respectively) 19 and the U.S. Food and Drug Administration criteria for tigecycline ( $\leq 2$ and $\geq 8 \mathrm{mg} /$ liter for susceptible and resistant, respectively). ${ }^{20}$ Isolates found to have imipenem, meropenem $\mathrm{MICs} \geq 1 \mathrm{mg} / \mathrm{L}$ or $\geq 0.5 \mathrm{mg} / \mathrm{l}$ for ertapenem and resistant to third generation cephalosporins were selected. Minimum inhibitory concentration (MIC) of imipenem, meropenem, ertapenem, were further confirmed by E test (AB Biodisk, Solna, Sweden). These isolates were screened for carbapenemases production by use of the MHT. ${ }^{16} \mathrm{~A} 1 / 10$ dilution of an inoculum of Escherichia coli ATCC 25922, adjusted to a 0.5 McFarland turbidity standard, was used to inoculate the surfaces of plates containing Mueller-Hinton agar by swabbing. After the plates were allowed to stand for $10 \mathrm{~min}$ at room temperature, meropenem disks MEM (Bio-Rad, California, USA) containing $(10 \mu \mathrm{g})$ were placed in the center of the plate. The test organism was streaked from the edge of the disk to the edge of the plate and incubated overnight at $37^{\circ} \mathrm{C}$ in ambient air for ${ }^{16-24}$ hours MHT Positive test has a clover leaf-like indentation of the E.coli 25922 growing along the test organism growth streak within the disk diffusion zone as shown in figure. ${ }^{1}$

Carbapenemase inhibition test: detection was performed with KPC/MBLs and OXA-48 Confirm Kit (Rosco Diagnostica) containing meropenem (10 ug), temocillin (30 ug), meropenem + BA (KPC and AmpC inhibitor), meropenem + DPA (MBLs inhibitor), meropenem + cloxacillin (CL) (AmpC inhibitor). ${ }^{18}$

A 0.5 McFarland inoculum was prepared and spread on Mueller-Hinton agar plates. Five disks were placed on each plate: meropenem, meropenem+ BA, meropenem + CL, meropenem + DPA, temocillin. Plates are incubated overnight at $35^{\circ} \mathrm{C}$. A positive response was achieved when there was a greater than $5 \mathrm{~mm}$ increase of the inhibition zone diameter around disks containing $\beta$-lactamase inhibitors, as compared with the meropenem disk alone as shown in Table 1. Negative results of all $\beta$-lactamase inhibitors, and no zone of inhibition with Temocillin $30 \mu \mathrm{g}$ is presumptive of an OXA-48.

Table 1. Interpretation of carbapenemase inhibition test

\begin{tabular}{|c|c|c|c|c|c|}
\hline \multirow{2}{*}{ Disc } & \multicolumn{3}{|c|}{ Classes of carbapenemases } & \multirow{2}{*}{ AmpC with porin loss } & \multirow{2}{*}{ ESBL with porin loss } \\
\hline & Class A & Class B & Class D & & \\
\hline Carbapenem + BA & + & - & - & + & - \\
\hline Carbapenem + cloxacillin & - & - & - & + & - \\
\hline Carbapenem + DPA & - & + & - & - & - \\
\hline Temocillin No zone of inhibition & - & - & + & - & - \\
\hline
\end{tabular}

ESBL: extended spectrum beta-lactamases

\section{RESULTS}

During the study period 54 out of 1350 Enterobacteriaceae isolates obtained from clinical samples were resistant to 3 rd generation cepalosporins and had elevated carbapenem MIC by microscan and E test. Among the 54 isolates, 24 (44.5\%) were positive for carbapenemase production by MHT. Using carbapenemase inhibition tests, 10 out of these 54 isolates were CPE as shown in table (2), represent- ing $(0.74 \%)$ of the 1350 examined Enterobacteriaceae. All the 10 isolates were sensitive to colistin and 9 were sensitive to tigecycline (table 3 ). The majority of these isolates were from patients in ICU $(n=6)$ and specimen source were tracheal aspirate $(n=5)$, urine $(n=3)$ and wound $(n=2)$ (table 4). All these patients had hospital stay for more than 5 days, previous antibiotic exposure for more than 7 days and 9 of them had indwelling device as shown in Table 5. 
Table 2. Species and carbapenem resistance mechanism of the 54 isolates by carbapenemase inhibition tests

\begin{tabular}{|c|c|c|c|c|c|c|}
\hline & CPE, A & CPE, B & CPE, D & AmpC with porin loss, $n$ & ESBL with porin loss, $n$ & Total, n \\
\hline E. coli & 1 & 2 & & 6 & 17 & 26 \\
\hline Klebsiella spp. & 1 & & 5 & 6 & 8 & 20 \\
\hline Enterobacter spp. & & & 1 & 0 & 4 & 5 \\
\hline Proteus & 0 & & & 1 & 2 & 3 \\
\hline Total, $\mathrm{n}(\%)$ & 2 & 2 & 6 & $13(24)$ & $3157.5 \%$ & $54100 \%$ \\
\hline
\end{tabular}

CPE: carbapenemase producing Enterobacteriaceae; ESBL: extended spectrum beta- lactamases

Table 3. Antibiotic susceptibility of the ten CPE isolates

\begin{tabular}{lccccccc}
\hline Isolate No & CN & AK & CIP & ATM & TZP & Colistin & Tigecycline \\
\hline 1 & $\mathrm{R}$ & $\mathrm{R}$ & $\mathrm{R}$ & $\mathrm{R}$ & $\mathrm{R}$ & $\mathrm{S}$ & $\mathrm{S}$ \\
2 & $\mathrm{R}$ & $\mathrm{R}$ & $\mathrm{R}$ & $\mathrm{R}$ & $\mathrm{R}$ & $\mathrm{S}$ & $\mathrm{S}$ \\
3 & $\mathrm{R}$ & $\mathrm{S}$ & $\mathrm{R}$ & $\mathrm{S}$ & $\mathrm{R}$ & $\mathrm{S}$ & $\mathrm{S}$ \\
4 & $\mathrm{R}$ & $\mathrm{R}$ & $\mathrm{R}$ & $\mathrm{R}$ & $\mathrm{I}$ & $\mathrm{S}$ & $\mathrm{R}$ \\
5 & $\mathrm{~S}$ & $\mathrm{~S}$ & $\mathrm{R}$ & $\mathrm{S}$ & $\mathrm{R}$ & $\mathrm{S}$ & $\mathrm{S}$ \\
6 & $\mathrm{R}$ & $\mathrm{R}$ & $\mathrm{R}$ & $\mathrm{R}$ & $\mathrm{R}$ & $\mathrm{S}$ & $\mathrm{S}$ \\
7 & $\mathrm{R}$ & $\mathrm{R}$ & $\mathrm{R}$ & $\mathrm{R}$ & $\mathrm{R}$ & $\mathrm{S}$ & $\mathrm{S}$ \\
8 & $\mathrm{R}$ & $\mathrm{S}$ & $\mathrm{R}$ & $\mathrm{R}$ & $\mathrm{R}$ & $\mathrm{S}$ & $\mathrm{S}$ \\
9 & $\mathrm{R}$ & $\mathrm{R}$ & $\mathrm{R}$ & $\mathrm{R}$ & $\mathrm{R}$ & $\mathrm{S}$ & $\mathrm{S}$ \\
10 & $\mathrm{R}$ & $\mathrm{R}$ & $\mathrm{R}$ & $\mathrm{R}$ & $\mathrm{R}$ & $\mathrm{S}$ & $\mathrm{S}$ \\
\hline
\end{tabular}

CN: gentamicin; Ak: amikacin; CIP: ciprofloxacin; ATM: azteronam; TZP: piperacillin/tazobactam

Table 4. Demographic and clinical characteristics of patients with carbapenemase producing Enterobacteriaceae

\begin{tabular}{lllllll}
\hline Isolate & Age & Sex & Location & Sample & Species & \multicolumn{2}{c}{$\begin{array}{c}\text { Carbapenemase } \\
\text { Class }\end{array}$} \\
\hline 1 & 24 & M & ICU & Tracheal aspirate & K. pneumoniae & Class D \\
2 & 38 & M & ICU & Urine & K. pneumoniae & Class D \\
3 & 55 & M & ICU & Tracheal aspirate & K. pneumoniae & Class A \\
4 & 28 & M & ICU & Tracheal aspirate & E.coli & Class B \\
5 & 31 & M & ICU & Wound Bed sore & E.coli & Class B \\
6 & 23 & M & MMW & Urine & Enterobacter spp. & Class D \\
7 & 57 & M & ICU & Tracheal aspirate & K. pneumoniae & Class D \\
8 & 63 & F & MMW & Urine & E.coli & Class A \\
9 & 62 & F & FMW & Tracheal aspirate & K. pneumoniae & Class D \\
10 & 41 & F & MSW & Wound & K. pneumoniae & Class D
\end{tabular}

$\mathrm{M}=$ male; $\mathrm{F}=$ female; $\mathrm{MMW}=$ male medical ward; $F M W=$ female medical ward; $F S W=$ female surgical ward;

Table 5. Potential Risk factors associated with Carbapenemase producing Enterobacteriaceae patients

\begin{tabular}{ll}
\hline Potential risk factor & No $(\%)$ \\
\hline Prolonged hospital stays $\geq 5$ days & $10(100)$ \\
Mechanical ventilation & $7(70)$ \\
Previous antibiotic exposure & $10(100)$ \\
Recent ICU stay & $8(80)$ \\
Indwelling device & $9(90)$ \\
\hline
\end{tabular}

\section{DISCUSSION}

Carbapenems are the antimicrobials of last resort to treat infections due to ESBL or plasmid-mediated AmpC producers of the Enterobacteriaceae family. ${ }^{21}$ Unfortunately, Carbapenemases were increasingly reported in Enterobacteriaceae in the past 10 years. Detection of infected patients and carriers with carbapenemase producers is necessary to prevent their spread. ${ }^{3}$ To our knowledge, our study is 
the first one documenting the epidemiology of CPE in the eastern province of Saudi Arabia. In a study reported by Swaminathan et al., the prevalence of carbapenem- resistant Enterobacteriaceae (CRE) was $5.4 \%$ Hidron et al. stated that carbapenem resistance was cited in up to $4.0 \%$ of Escherichia coli and $10.8 \%$ of $K$. pneumoniae isolates reported to the National Healthcare Safety Network..$^{22,23}$ Gupta et al. noted that resistance within $K$. pneumoniae alone increased from $0.6 \%$ in 2004 to $5.6 \%$ in 2008. ${ }^{1}$ In these studies CPE prevalence was much higher than our study in which CPE represented only $(0.74 \%)$ of the isolated Enterobacteriaceae.

In the present study, although MHT was positive for 24 isolates, only 10 isolates were confirmed to produce carbapenemase by the carbapenemase inhibition test. This is in agreement with earlier studies in which MHT was reported to have high sensitivity (95 to $100 \%) ; 2$ however, its specificity was questioned since false-positive results were observed with strains producing ESBLs or AmpC with decreased porins..$^{17,24}$ On the other hand, van Dijk et al., concluded that carbapenemase inhibition tests withjoint PBA and DPA with a temocillin disc offer a reliable phenotypic confirmation method for class $A$, $B$ and OXA-48 carbapenemases in Enterobacteriaceae. ${ }^{18}$ Temocillin is a semi-synthetic derivative of ticarcillin and its activity is almost only limited to the Enterobacteriaceae. ${ }^{25}$ Since OXA-48 confers highlevel temocillin resistance, a disc diffusion assay using temocillin is used for its detection. ${ }^{18,25}$ Bartolin et al. obtained the most accurate identification of resistance determinants with the combined disc test (Rosco Diagnostica KPC and MBL confirm kit) which had to be coupled with the cloxacillin inhibition test for correct detection of AmpC enzymes. ${ }^{26}$

Out of the 54 CRE isolates $44(81.5 \%)$ were ESBL or AmpC with porin loss producers whereas $10(18.5 \%)$ were CPE which suggest that although $\mathrm{CPE}$ is emerging, It does not play a major role in carbapenem resistance in our setting This also may explains our earlier experience with ESBL-producing Enterobacteriaceae in the same setting during (2011-2012) in which $20 \%$ of ESBL isolates were CRE. ${ }^{27}$

In our study all CPE were susceptible to colistin and all but one were susceptible to tigecycline. This is in agreement with both Hara et al., who reported that in vitro susceptibility to colistin among CPE isolates ranged from 80 to $100 \%$ and Landman et al, who stated that $100 \%$ and $99.8 \%$ of the tested isolates were sensitive to colistin and tigecycline respectively. ${ }^{21,28}$ In Endimiani et al. study, The AST results showed that the therapeutic options against serious infections due to KPC - $K$. pneumoniae strains were limited to tigecycline and colistin. ${ }^{29}$ Also, balkhy concluded that carbapenem resistant $K$. pneumoniae had $90-100 \%$ resistance to most antimicrobial agents, including carbapenems, cephalosporins, and fluoroquinolones; however they remained sensitive to colistin and to a lesser extent, to glycylcyclines. ${ }^{9}$

In our study 6 isolates were class D, 2 isolates were class $B$ and class $A$ each. OXA-48-producing $K$. pneumoniae isolates were first described in Turkey, and later emerged in the Middle East, India, Europe, and North Africa Which are considered as reservoirs of OXA-48 producers ${ }^{2,8,30}$ In Saudi Arabia The first, documented outbreak of carbapenem-resistant $K$. pneumoniae occurred in Riyadh and carried the carbapenemase gene blaOXA-48. ${ }^{9}$ More recently Shibl et al. reported that OXA-48 was detected in $47(78 \%)$ of CPE isolates. They speculated that a high frequency of population movement with Turkey, where K. pneumoniae with blaOXA-48 is endemic, might explain the high occurrence of isolates with this resistance gene in their setting. ${ }^{31}$ In United Arab Emirates OXA-48-like was found in 11 isolates out of 34 carbapenem resistant Enterobacteriaceae while in Kuwait one OXA-48 isolate was detected incidentally in 2011. ${ }^{32}$

As showed before, clinically significant carbapenemases are mostly carried and expressed by $K$. pneumoniae isolates and are often associated with serious nosocomial infections and outbreaks. ${ }^{31,5,3}$ In our setting ,60\% of carbapenemases were found in K. pneumoniae. In the present study, 6 out of $10 \mathrm{CPE}$ isolates were detected in ICU and 5 were detected in tracheal aspirates. This is in agreement with both Chitnis et al. and Teo et al. who found that independent risk factors for CRE infection included mechanical ventilation. ${ }^{33,34}$ Similarly , in other studies ICU stay was a risk factor for CPE acquisition ${ }^{12,13}$ In a study made by Shibl et al. $75 \%$ of CPE isolates were detected in ICU patients. ${ }^{31}$

In the current study many of potential risk factors for CPE acquisition were observed. This is similar to previous reports describing these risk factors, including prolonged hospital stay, antimicrobials exposure, mechanical ventilation, pulmonary disease, current stay in the ICU and use of indwelling device as the most prominent ones. ${ }^{12,13,34}$ 


\section{CONCLUSION}

Since CPE is emerging in our setting and since treatment options are very limited, early detection using $\mathrm{MHT}$ together with carbapenemase inhibition tests should be done. Awareness of their entry into the hospital environment together with strict infection control measures will help limiting their further spread which can be difficult to control if they evolved to endemicity.

\section{Conflict of interest statement: None declared.}

\section{Funding source: None}

\section{REFERENCES}

1. Gupta N, Limbago BM, Patel JB, Kallen AJ. Carbapenem-resistant Enterobacteriaceae: epidemiology and prevention. Clin Infect Dis 2011;53:60-67.

2. Birgy A, Bidet P, Genel N et al. Phenotypic screening of carbapenemases and associated $\beta$-lactamases in carbapenem-resistant Enterobacteriaceae. J Clin Microbiol 2012;50:1295-1302.

3. Nordmann P, Naas T, Poirel L. Global spread of carbapenemaseproducing Enterobacteriaceae. Emerg Infect Dis 2011; 17:17911798.

4. Queenan AM, Bush K. Carbapenemases: the versatile ß-lactamases. Clin Microbiol Rev 2007;20:440-458.

5. Nordmann P, Cuzon G, Naas T. The real threat of Klebsiella pneumoniae carbapenemase-producing bacteria. Lancet Infect Dis 2009;9:228-236

6. Navon-Venezia S, Leavitt A, Schwaber MJ, et al. First report on a hyperepidemic clone of KPC-3-producing Klebsiella pneumonia in Israel genetically related to a strain causing outbreaks in the United States. Antimicrob Agents Chemother 2009;53:818-820.

7. Walsh TR, Toleman MA, Poirel L, Nordmannn P. Metallo- $\beta-$ lactamases: the quiet before the storm? Clin Microbiol Rev 2005; 18:306-325.

8. Poirel L, Héritier C, Tolün V, Nordmann P. Emergence of oxacillinase-mediated resistance to imipenem in Klebsiella pneumoniae. Antimicrob Agents Chemother 2004;48:15-22.

9. Balkhy HH, El-Saed A, Al Johani SM, et al. The epidemiology of the first described carbapenem- resistant Klebsiella pneumonia outbreak in a tertiary care hospital in Saudi Arabia: how far do we go? Eur. J. Clin. Microbiol. Infect. Dis. 2012; 31:1901-1909.

10. Poirel L, Al Maskari Z, Al Rashdi F, et al. NDM-1-producing Klebsiella pneumoniae isolated in the Sultanate of Oman. J Antimicrob Chemother 2011;66:304-306.

11. Dortet L, Poirel L, Al Yaqoubi F, Nordmann P. NDM-1, OXA-48 and OXA-181 carbapenemase-producing Enterobacteriaceae in Sultanate of Oman. Clin Microbiol Infect 2012;18:E144-E148.

12. Maragakis LL. Recognition and prevention of multidrug-resistant Gram-negative bacteria in the intensive care unit. Crit Care Med. 2010;38(Suppl 8):S345-351.

13. Patel G, Huprikar S, Factor SH, et al. Outcomes of carbapenemresistant Klebsiella pneumonia infection and the impact of antimicrobial and adjunctive therapies. Infect Control Hosp Epidemiol. 2008;29:1099-106.

14. Hong T, Moland E, Abdalhamid B, et al. Escherichia coli: development of carbapenem resistance during therapy. Clin Infect Dis 2005;40:e84-e86.

15. Clinical and Laboratory Standards Institute 2012. Performance standards for antimicrobial susceptibility testing: 22nd informational supplement. . CLSI document M100-S22. Clinical and Laboratory Standards Institute, Wayne, PA

16. Clinical and Laboratory Standards Institute. 2009. Performance standards for antimicrobial susceptibility testing: 20th informa- tional supplement. CLSI document M100-S20. Clinical and Laboratory Standards Institute, Wayne, PA.

17. Carvalhaes CG, Picao RC, Nicoletti AG, et al. Cloverleaf test (modified Hodge test) for detecting carbapenemase production in Klebsiella pneumoniae: be aware of false positive results. $J$ Antimicrob Chemother 2010;65:249-251.

18. Van Dijk K, Voets GM, Scharringa J, et al. Disc diffusion assay for detection of class A, B and OXA-48 carbapenemases in Enterobacteriaceae using phenyl boronic acid, dipicolinic acid and temocillin. Clin Microbiol Infect 2014;20:345-349.

19. European Committee on Antimicrobial Susceptibility Testing (EUCAST). Breakpoint tables for interpretation of MICs and zone diameters, version 1.3, January 5, 2011. EUCAST, Växjö, Sweden.

20. Kronvall G, Karlsson I, Walder M, et al. Epidemiological MIC cutoff values for tigecycline calculated from E test MIC values using normalized resistance interpretation. J Antimicrob Chemother 2006;57:498-505

21. Hara G, Gould I, Endimiani A, et al. Detection, treatment, and prevention of carbapenemase-producing Enterobacteriaceae: recommendations from an International working group. J Chemother 2013;25:129-140.

22. Swaminathan M, Sharma S, Blash SP, et al. Prevalence and Risk Factors for Acquisition of Carbapenem-Resistant Enterobacteriaceae in the Setting of Endemicity. Infect Control Hosp Epidemiol 2013;34:809-817.

23. Hidron Al, Edwards JR, Patel J, et al. NHSN annual update: antimicrobial resistant pathogens associated with healthcareassociated infections: annual summary of data reported to the National Healthcare Safety Network at the Centers for Disease Control and Prevention, 2006-2007. Infect Control Hosp Epidemiol 2008;29:996-1011.

24. Pasteran F, Mendez T, Rapoport M, et al. Controlling false-positive results obtained with the Hodge and Masuda assays for detection of class A carbapenemase in species of Enterobacteri-aceaeby incorporating boronic acid. J Clin Microbiol 2010;48:1323-1332.

25. Livermore DM, Tulkens PM. Temocillin revived. J Antimicrob Chemother 2009; 63:243-245.

26. Bartolini A, Frasson I, Cavallaro A, et al. Comparison of phenotypic methods for the detection of carbapenem non-susceptible Enterobacteriaceae. Gut Pathog 2014;6:1-7.

27. Kandeel A. Prevalence and risk factors of extended-spectrum $\beta$-lactamases producing Enterobacteriaceaein a general hospital in Saudi Arabia. J Microbiol Infect Dis 2014; 4:50-54.

28. Landman D, Urban C, Backer M, et al. Susceptibility profiles, molecular epidemiology, and detection of KPC-producing Escherichia coli isolates from the New York City vicinity. J Clin Microbiol 2010;48:4604-4607.

29. Endimiani A, Depasquale JM, Forero S, et al. Emergence of blaKPC-containing Klebsiella pneumoniaein a long-term acute care hospital: a new challenge to our healthcare system. J Antimicrob Chemother 2009;64:1102-1110.

30. Poirel L, Potron A, Nordmann P. OXA-48-like carbapenemase: the phantom menace, J. Antimicrob Chemother. 2012;67:15971606.

31. Shibl A, Al-Agamy M, Memish Z, et al. The emergence of OXA48- and NDM-1-positive Klebsiella pneumoniae in Riyadh, Saudi Arabia. Int J Infect Dis 2013; 17: e1130-e1133

32. Zowawi H, Balkhy H, Walsh T, Patersona D. $\beta$-Lactamase Production in Key Gram-Negative Pathogen Isolates from the Arabian Peninsula Clin. Microbiol Rev 2013;26:361-380.

33. Chitnis AS, Caruthers PS, Rao AK, et al. Outbreak of carbapenem-resistant Enterobacteriaceae at a long-term acute care hospital: Sustained reductions in transmission through active surveillance and targeted interventions. Infect Control Hosp Epidemiol 2012;33:984-992.

34. Teo J, Cai Y, Tang S, et al. Risk Factors, Molecular Epidemiology and Outcomes of Ertapenem-Resistant, Carbapenem-Susceptible Enterobacteriaceae: A Case-Case-Control Study. PLoS One 2012; 7:e34254. 